\title{
KORELASI KREATIFITAS GURU PENDIDIKAN AGAMA ISLAM DAN PRESTASI BELAJAR SISWA TERHADAP PENGAMALAN AGAMA ISLAM SISWA KELAS XII DI SMKN 2 MALANG
}

\author{
Isnawati Nurafifah Latif \\ Program Studi Pendidikan Agama Islam, Fakultas Tarbiyah IAINU TUBAN \\ email: isnawatinurafifahlatif@gmail.com
}

\author{
Siti Nurjanah \\ Program Studi Pendidikan Guru Madrasah Ibtidaiyah, Fakultas Tarbiyah IAINU TUBAN \\ email: sn.janah08@gmail.com
}

\begin{abstract}
Abstrak
Pendidikan menjadi kunci peningkatan kualitas sumberdaya manusia Indonesia. Pendidikan Agama Islam menjadi bagian yang terintegrasi dalam kehidupan bermasyarakat mengingat mayoritas penduduk penganut agama Islam. Fakta ini menjadikan Pendidikan Agama Islam sebagai faktor penting pembentuk kepribadian bangsa. Sekolah menjadi salah satu tempat diberikan Pendidikan agama Islam dengan dengan sistem terukur melalui kurikulum. Pencapaian keberhasilan pendidikan Agama Islam di sekolah dalam penelitian ini diukur dengan varibel Kreatifitas Guru $\left(\mathrm{X}_{1}\right)$, Prestasi Belajar $\left(\mathrm{X}_{2}\right)$, dan Pengamalan Agama siswa (Y). Asumsi yang digunakan bahwa kreatifitas guru dan prestasi siswa akan memberi pengaruh terhadap pengamalan Agama Islam siswa di SMKN 2 Malang. Teknik pengumpulan data menggunakan metode angket, dokumentasi dan skala Likert. Metode analisis menggunakan analisis korelasi dan regresi. Pengolahan data menggunakan software SPSS 25. Metode yang dipakai yaitu single (enter) dan bukan menggunakan metode stepwise. Uji hasil pengukuran dengan uji reabilitas dengan taraf nyata 5\%. menggunakan koefisien aloha cronbach. Diperoleh nila $\mathrm{F}$ sebesar 3,546 dengan nilai signifikan 0,03 yang berarti varibel Kreatifitas Guru $\left(\mathrm{X}_{1}\right)$, Prestasi Belajar $\left(\mathrm{X}_{2}\right)$ memberi pengaruh signifikan terhadap Pengamalan Agama siswa (Y). Berlainan dengan hasil uji t sebesar 0,269 dengan nilai signifikan 0,012 menunjukkan Kreatifitas Guru $\left(\mathrm{X}_{1}\right)$ dan Prestasi Belajar $\left(\mathrm{X}_{2}\right)$ tidak memberi pengaruh signifikan terhadap Pengamalan Agama siswa (Y) SMKN 2 Malang.
\end{abstract}

Kata kunci: kreatifitas guru, Pendidikan Agama Islam, pengamalan agama, prestasi belajar

\section{PENDAHULUAN}

Pendidikan memiliki peran stategis dalam memajukan suatu negara karena pendidikan akan meningkatkan kualitas sumberdaya manusia. Mengingat Indonesia negara dengan mayoritas beragama Islam maka keberadaan pendidikan Agama Islam secara khusus berada pada posisi tidak kalah penting dengan pendidikan lainnya. Pendidikan agama diperlukan sebagai sarana mengarahkan kepribadian masyarakat menuju kepribadian yang luhur sesuai dengan Pancasila. Pendidikan juga berperan menumbuhkan kesadaran. Kesadaran pribadi yang akan mendukung kesadaran bermasyarakat. Warga negara yang kesadaran sosial tinggi akan mengarah pada keadaan negara yang tertib dan keberlangsungan kehidupan masyarakatnya mempunyai daya semangat tinggi membangun negara. Othman (2014:7) memaparkan, pendidikan agama lebih dari sekedar 
menumbuhkan spiritual tetapi menjadi pendorong dominan terhadap perilaku penganutnya. Manusia, dari sisi perkembangan pribadinya meliputi banyak aspek, fisik, mental, kepribadian termasuk di dalamnya spiritual. Hal yang sangat penting untuk mencetak manusia yang mulia dapat dilihat dari pengaturan diri pribadi, interaksi dalam keluarga, masyarakat dan termasuk di dalamnya pengamalan agama yang dilakukan.

Kesadaran manusia akan kewajiban beragama terutama dalam lingkup sekolah memiliki hubungan berbagai aturan dan kegiatan yang berada di lingkup sekolah (Zaini dan Setyono, 2020: 57). Keberadaan sistem kurikulum akan membuat pendidikan Agama Islam yang akan dan sudah dilakukan terukur hasilnya.

Pendidikan memiliki peran penting yang membutuhkan sistem untuk menerapkan sehingga hasil pendidikan tersebut mencapai target. Nugroho, dan Ni'mah (2018:341), menjelaskan keberhasilan pembelajaran melibatkan banyak pihak dan banyak faktor, seperti sekolah, guru, murid, masyarakat dan orang tua. Peran utama proses belajaran yang dilakukan di sekolah dilakukan oleh guru dan murid. Guru ditantang untuk terus melakukan terobosan dalam proses pembelajaran. Ilmu yang disampaikan kepada siswa sebagai proses penanaman nilai, sehingga sikap yang dibentuk menjasi pengalaman dari agama Islam. Djohar (2006:137), menambahkan guru berperan dominan sebagai kreator kelas yang berperan mengarahkan proses pembelajaran menjadi optimal. Guru dituntut untuk mampu menggerakan kelas atau kondisi belajar menjadi aktif dan berjalan baik sehingga pencapaian tujuan pencapaian pembelajaran diperoleh.

Pendidikan masa sekarang mendapat tantangan berbeda dengan masa pendidikan 20 tahun yang lalu. Murid-murid sekarang bisa mendapat berbagai macam sumber pengetahuan dari banyak sumber. Tidak menutup kemungkinan artikel-artikel yang belum diverifikasi. Di bagian ini Agama Islam menjalan peran yang diharapkan mampu berpengaruh terhadap perilaku siswa di mana pun mereka berada, pun ketika mereka berinteraksi dengan teknologi. Variasi sumber ini menjadi tantangan sistem pendidikan untuk tetap menjadi pengarah kualitas siswa secara teratur Pendidikan dan terukur.

Pendidikan yang baik melibatkan guru dan siswa secara aktif dan proporsional, tetapi secara umum proses pendidikan di Indonesia masih dominan satu arah saja yaitu dari guru ke murid. Kelangsungan pendidikan dengan cara seperti ini mendorong guru untuk mengelola kelas secara aktif (berkreatifitas). Subhan (2013:362), menjelaskan dalam sejarah pendidikan manusia selalu berusaha menemukan bentuk dinamis karena antara pendidikan dan manusia (masyarakat) akan terus saling mempengaruhi.

Pendidikan Agama Islam (PAI) menjadi penting terlebih mayoritas penduduk Indonesia adalah muslim. Artinya pendidikan agama Islam siswa sudah mendapat terlebih dahulu dari 
lingkungan keluarga. Agama Islam memiliki hukum-hukum sebagai pengarah kehidupan pemeluknya. Siswa merupakan manusia yang sedang tumbuh dan berada pada level remaja, sehingga pengamalan Agama Islam mereka masih dalam fase diarahkan oleh guru untuk lingkup sekolah. Tujuan Pendidikan di Sekolah Menengah Atas (SMA), Sekolah Menengah Kejuruan (SMK), atau Madrasah Aliyah (MA) bertujuan membangun akidah melalui pembelajaran, pendalaman pengetahuan diikuti pembiasaan dan pengamalan. Harapan yang dituju yaitu menjadi manusia bertakwa kepada Allah SWT.

Keberadaan sumberdaya siswa, dan target pembelajaran maka instrumen pendidikan diperlukan untuk menjadi tolok ukur keberhasilan atau permasalahan yang dihadapi. Meskipun kualitas dari berbagai sekolah berbeda, makan keberadaan instrumen pendidikan akan memberi informasi keberhasilan proses pembelajaran tersebut. Kemudian hasil yang diperoleh dapat dievaluasi untuk perbaikan proses pembelajaran selanjutnya.

Keterkaitan antara beberapa faktor pendukung pendidikan Agama Islam dalam penelitian ini yang ditinjau yaitu kreatifitas guru, prestasi siswa dan pengamalan siswa. Penelitian menggunakan variabel kreatifitas guru $\left(\mathrm{X}_{1}\right)$ dan variabel prestasi siswa $\left(\mathrm{X}_{2}\right)$ yang diukur pengaruhnya terhadap variabel Pengamalan Agama (Y) siswa kelas XII SMKN 2 Malang. Diharapkan akan diketahui variabel mana yang saling memberi pengaruh signifikan atau tidak sama sekali mempengaruhi. Digunakan penelitian dengan metode survei. Sugiono (2011:12), memaparkan penelitian dengan metode survei dilakukan untuk mengambil pengamatan secara umum, tetapi tidak mendalam. Meskipun demikian penggunaan sampel yang respresentatif dalam metode survei akan memperoleh pengamatan umum yang akurat.

\section{METODOLOGI}

\section{Rancangan Penelitian dan Sumber Data}

Penelitian dilakukan di SMKN 2 Malang. Penelitian ini dengan metode kuantitatif survei. Instrumen penelitian yaitu vaiabel $\mathrm{X}_{1}$ merupakan kreatifitas guru, $\mathrm{X}_{2}$ variabel prestasi siswa, dan $\mathrm{Y}$ variabel pengamalan siswa

Menurut Nisfianoor, (2009:9), pengujian kebenaran menggunakan uji hipotesis, yaitu hipotesis nol $\left(\mathrm{H}_{0}\right)$ sebagai hal yang diuji dan hipotesis alternatif $\left(\mathrm{H}_{\mathrm{a}}\right)$ sebagai hasil penelitian. Peluang kesalahan alpha $(\alpha)$ menggunakan taraf sisgnifiksasi sebagai berikut:

a. sangat signifikan jika, $(p) \leq 0,01$

b. signifikan jika, $(\mathrm{p}) \leq 0,05$

c. tidak signifikan jika, $(\mathrm{p}) \geq 0,05$ 


\section{Teknik Pengumpulan Data}

Pengumpulan data dilakukan dengan metode angket, dokumentasi dan skala pengukuran mengguanakan skala Likert. Variabel kreativitas guru $\left(\mathrm{X}_{1}\right)$ diukur dengan 24 item pernyataan yang dibangun dari Sembilan indikator, yaitu:

a. Kelancaran berpikir, terdiri dari 4 item pernyataan (nomor 1 sampai dengan 4).

b. Keluwesan berpikir, terdiri dari 5 item pernyataan (nomor 5 sampai dengan 9).

c. Keaslian berpikir, terdiri dari 3 item pernyataan (nomor 10 sampai dengan 12).

d. Elaborasi (merinci), terdiri dari 3 item pernyataan (nomor 13 sampai dengan 15).

e. Rasa ingin tahu, terdiri dari 3 item pernyataan (nomor 16 sampai dengan 18).

f. Merasa tertantang oleh kemajemukan, terdiri dari 2 item pernyataan (nomor 1 sampai dengan 4).

g. Berani mengambil resiko, terdiri dari 4 item pernyataan (nomor 21 sampai dengan 22).

h. Sifat menghargai, terdiri dari 2 item pernyataan (nomor 23 sampai dengan 24).

Validitas instrumen dilakukan dengan membandingkan indeks korelasi product moment Pearson dengan nilai signifikan 5\%, membandingkan antara $r_{\text {hitung }}$ dan $r_{\text {tabel }}$. Uji untuk hasil pengukuran digunakan uji reabilitas dengan taraf nyata 5\% menggunakan koefisien aloha cronbach.

Variabel prestasi siswa $\left(\mathrm{X}_{2}\right)$ diukur dari nilai ulangan harian siswa, sedangkan variabel ketiga yaitu pengamalan agama siswa (Y) diukur dengan 17 pernyataan yang dirujuk dari indikator Kompetensi Dasar Pendidikan Agama Islam kelas XII, yaitu mampu mempraktikkan perilaku bertoleransi.

Teknik pengumpulan data menggunakan kuisioner, tes, interview dan dokumentasi. Metode analisis menggunakan analisis korelasi dan regresi.

\section{Analisis Data}

Pengolahan data menggunakan software SPSS 25. Metode yang dipakai yaitu single (enter) dan bukan menggunakan metode stepwise.

Tabel 1. Metode Analisis SPSS 25 dengan Variabel $\mathrm{X}_{1}$ dan $\mathrm{X}_{2}$

\section{Variables Entered/Removedb}

\begin{tabular}{|l|l|l|l|}
\cline { 4 - 4 } Model & Variable & Variable & Method \\
\hline 1 & $\mathbf{s}$ & $\mathbf{s}$ & \\
& $\begin{array}{l}\text { v_prestasi_siswa } \\
\text { v_kreativitas_gur } \\
\text { ua }\end{array}$ & & Enter \\
\hline
\end{tabular}

a. All requested variables entered.

b. Dependent Variable: v_pengamalan_agama_siswa 
Tabel 1. di atas menggambarkan metode single enter tanpa ada variabel yang dikeluarkan (removed) antara variabel Kreatifitas Guru $\left(\mathrm{X}_{1}\right)$, dan Prestasi Belajar $\left(\mathrm{X}_{2}\right)$. Sehingga data yang diperoleh dipergunakan semua untuk diolah.

\section{HASIL DAN PEMBAHASAN}

Penelitian dilaksanaka di SMK Negeri 2 Malang kelas XII dengan siswa sejumlah 87. pengolahan data menggunakan software SPSS 25. Variabel penelitian ini antara lain, Kreatifitas Guru $\left(\mathrm{X}_{1}\right)$, Prestasi Belajar $\left(\mathrm{X}_{2}\right)$, Pengamalan Agama (Y).

\section{Hasil Penelitian}

\section{Uji Validitas Data}

Pengujian validitas data dari 40 responden dengan $r$ tabel 0,312 dengan taraf signifikan 5\%. diperoleh nilai Pearson (rhitung) lebih besar dari pada $r$ tabel sehingga disimpulkan bahwa data valid.

\section{Pengujian reabilitas Data}

Taraf nyata 5\% digunakan untuk uji reabilitas menggunakan koefisien alpha cronbach. Data menjadi real bila nilai alpha cronbach lebih besar dari angka 0,6

Tabel 2. Hasil Pengujian Reabilitas Variabel

\begin{tabular}{|l|l|l|}
\hline Variabel & Cronbach's alpha & N of items \\
\hline Kreatifitas guru & 0,961 & 24 \\
Pengamalan agama siswa & 0,886 & 17 \\
\hline
\end{tabular}

Berdasar hasil tersebut terlihat bahwa instrumen penelitian berstatus layak untuk digunakan sebagai alat ukur.

\section{Karakteristik Obyek Penelitian}

Obyek penelitian yaitu SMKN 2 Malang kelas Xll mempunyai siswa laik-laki sejumlah 39 dan siswa perempuan sejumlah 48, sehingga keseluruhan 87 siswa. Pengukuran prestasi siwa dilakukan berdasarkan ulangan dari Pendidikan Agama Islam, perolehan distribusi nilai ditunjukkan tabel di bawah ini. 
Tabel 3. Distribusi Frekuensi Nilai Ulangan PAI Siswa kelas XII

\begin{tabular}{|c|c|}
\hline Nilai & Frekuensi \\
\hline $75,1-77,1$ & 9 \\
\hline $78,1-80,1$ & 11 \\
\hline $81,1-83,1$ & 13 \\
\hline $84,1-86,1$ & 18 \\
\hline $87,1-89,1$ & 15 \\
\hline $90,1-92,1$ & 7 \\
\hline $93,1-95,1$ & 7 \\
\hline $96,1-98,1$ & 7 \\
\hline Jumlah & 87 \\
\hline
\end{tabular}

Siswa distribusi nilai 84,1 hingga 86,1 mempunyai frekuensi terbanyak sebesar 18, sedangkan distribusi nilai terendah rentang 75,1 hingga 77,1 mempunyai frekuensi 9.

\section{Hasil Penggambaran Variabel}

Perolehan jawaban kuisioner ditampilkan dalan nilai rata-rata (mean) untuk variabel Kreatifitas Guru $\left(\mathrm{X}_{1}\right)$.

Tabel 4. Hasil Jawaban Kuisioner dan Rata-rata Skor Jawaban Variabel Kreatifitas Guru

\begin{tabular}{|c|c|c|c|}
\hline No. & Indikator & mean & Total mean \\
\hline 1. & Kelancaran berpikir & 3,92 & \multirow{8}{*}{3,25} \\
\hline 2. & Keluwesan berpikir & 3,81 & \\
\hline 3. & Keaslian berpikir & 3,38 & \\
\hline 4. & Elaborasi (merinci) & 3,87 & \\
\hline 5. & Rasa ingin tahu & 3,68 & \\
\hline 6. & Merasa tertantang oleh kemajemukan & 3,3 & \\
\hline 7. & Berani mengambil resiko & 3,11 & \\
\hline 8. & Sifat menghargai & 4,05 & \\
\hline
\end{tabular}

\section{Hasil Pengujian Hipotesis} penelitian.

Penghitungan data menggunakan SPSS 16 untuk menganalisis data dari setiap variabel 
Tabel 5. Hasil Deskripsi Statistik Variabel Kreatifitas Guru, Prestasi Siswa, dan Pengamalan Siswa SMKN 2 Malang

\begin{tabular}{|l|c|c|c|}
\hline \multicolumn{1}{|c|}{ Variabel } & Rata-rata & Standar deviasi & N \\
\hline Pengamalan agama siswa & 67.0920 & 5.81624 & 87 \\
kreatifitas guru & 88.2644 & 10.05735 & 87 \\
prestasi siswa & 85.4747 & 6.03423 & 87 \\
\hline
\end{tabular}

Berdasarkan tabel di atas pengamalan siswa digambarkan oleh nilai rata-rata (mean) sebesar $67,09(\mathrm{Y})$, sedangkan kreatifitas guru $\left(\mathrm{X}_{1}\right)$ dengan nilai 88,26, dan prestasi siswa $\left(\mathrm{X}_{2}\right)$ dengan nilai sebesar 85,47. nilai standar deviasi terbesar dimiliki oleh variabel Kreatifitas Guru dengan nilai 10,057 .

Tabel 6. Hasil Korelasi Regresi dari Kreatifitas Guru, Prestasi Siswa, dan Pengamalan Siswa

\begin{tabular}{|l|l|l|l|l|}
\hline & variabel & $\begin{array}{l}\text { Pengamalan } \\
\text { agama siswa }\end{array}$ & $\begin{array}{l}\text { Kreativitas } \\
\text { guru }\end{array}$ & $\begin{array}{l}\text { Prestasi } \\
\text { siswa }\end{array}$ \\
\hline $\begin{array}{l}\text { Pearson } \\
\text { correlation }\end{array}$ & Pengamalan agama siswa & 1,000 & 0,274 & 0,077 \\
& Kreativitas guru & 2,74 & 1,000 & 0,79 \\
& Prestasi siswa & 0,077 & 0,079 & 1,000 \\
\hline 1-tailed & Pengamalan agama siswa & & 0,005 & 0,240 \\
& Kreativitas guru & 0,005 & 0,235 \\
\hline $\mathrm{N}$ & Prestasi siswa & 0,240 & 0,235 & \\
& Pengamalan agama siswa & 87 & 87 & 87 \\
& Kreativitas guru & 87 & 87 & 87 \\
& Prestasi siswa & 87 & 87 & 87 \\
\hline
\end{tabular}

Tabel 5 menjelaskan bahwa korelasi yang diperoleh antara Kreatifitas guru $\left(\mathrm{X}_{1}\right)$ dan Pengamalan siswa (Y) sebesar 0,274. nilai signifikan untuk korelasi adalah 1, sehingga hasil tersebut menunjukkkan korelasi antara Kreatifitas guru $\left(\mathrm{X}_{1}\right)$ dan Pengamalan siswa (Y) kecil sekali. Begitu juga korelasi antara Prestasi Belajar $\left(\mathrm{X}_{2}\right)$ dan Pengamalan siswa $(\mathrm{Y})$ diperoleh hasil kecil yaitu 0,077 . 
Tabel 7. Hasil Statistik Ada Tidaknya Pengaruh Variabel $\mathrm{X}_{1}$ dan $\mathrm{X}_{2}$ terhadap $\mathrm{Y}$

ANOVAb

\begin{tabular}{|l|c|c|c|c|c|}
\hline Model 1 & Sum of square & df & Mean square & F & Sig. \\
\hline Regresi & 228,525 & 2 & 113,263 & 3,546 & $0,033 \mathrm{a}$ \\
Residual & 2682,739 & 84 & 31,937 & & \\
Total & 2909,264 & 86 & & & \\
\hline
\end{tabular}

a. Predictors: (Constant), v_prestasi_siswa, v_kreativitas_guru

Nilai F sebesar 3,546 dengan nilai signifikan 0, 033 yang ditunjukkan oleh Tabel 7. memberikan arti bahwa ada pengaruh dari variabel Kreatifitas Guru $\left(\mathrm{X}_{1}\right)$, dan Prestasi Belajar $\left(\mathrm{X}_{2}\right)$ terhadap variabel Pengamalan Agama Siswa (Y). Hal ini kemudian diperjelas oleh korelasi berganda pada analisis regresi dengan hasil pada Tabel 8

Tabel 8. Hasil Korelasi Berganda antara Variabel $\mathrm{X}_{1}$ dan $\mathrm{X}_{2}$ terhadap $\mathrm{Y}$

\begin{tabular}{|l|l|c|c|c|c|c|}
\hline Model & \multicolumn{1}{|c|}{ Variabel } & \multicolumn{2}{|c|}{$\begin{array}{c}\text { Unstandardized } \\
\text { coefficients }\end{array}$} & $\begin{array}{c}\text { Unstandardized } \\
\text { coefficients Beta }\end{array}$ & t & Sig. \\
\cline { 3 - 5 } & & B & Standar error & & \\
\hline \multirow{2}{*}{1} & Konstanta & 48,782 & 9,840 & & 4,957 & 0,000 \\
& kreativitas guru & 0,156 & 0,061 & 0,269 & 2,561 & 0,012 \\
& preatasi siswa & 0,053 & 0,101 & 0,055 & 0,528 & 0,599 \\
\hline
\end{tabular}

b. Dependent Variable: v_pengamalan_agama_siswa

Hasil dari Tabel 8 menunjukkan korelasi antara Kreatifitas guru $\left(\mathrm{X}_{1}\right)$ dan Pengamalan Siswa ( Y) melalui persamaan $\mathrm{Y}=48,782+0,156 \mathrm{X}_{1}$ sedangkan korelasi antara Prestasi Siswa $\left(\mathrm{X}_{2}\right)$ dan Pengamalan Siswa ( Y) ditunjukkan oleh persamaan $\mathrm{Y}=48,782+0,0,053 \mathrm{X}_{2}$.

Berdasarkan persamaan $\mathrm{Y}=48,782+0,156 \mathrm{X}_{1}$ jika Kreatifitas guru $\left(\mathrm{X}_{1}\right)$ tidak meningkat atau secara angka disebut dengan 0 (nol) maka Pengamalan Siswa ( Y) akan mempunyai nilai 48,782 yaitu nilai konstanta itu sendiri. Demikian juga untuk menghitung berdasarkan variabel Prestasi Siswa $\left(\mathrm{X}_{2}\right)$ menggunakan persamaan $\mathrm{Y}=48,782+0,0,053 \mathrm{X}_{2}$. Jika prestasi siswa $\left(\mathrm{X}_{2}\right)$ tidak ada kenaikan atau secara angka diberikan angka 0 (nol) maka Pengamalan Siswa ( Y) akan mempunyai nilai 48,782 juga.

Kolom Standardized Coefficients Beta menunjukkan tingkat korelasi, yaitu antara Kreatifitas guru $\left(\mathrm{X}_{1}\right)$ terhadap Pengamalan Siswa ( Y) mempunyai nilai 0,269, sedangkan nilai signiifikan sebesar 0,012. nilai ini lebih kecil dari 5\% ( $<0,05)$ menunjukkan terdapat pengaruh Kreatifitas guru $\left(\mathrm{X}_{1}\right)$ terhadap Pengamalan Siswa ( Y). Standardized Coefficients Beta dengan nilai 0,055 yang menunjukkan korelasi Prestasi Siswa $\left(\mathrm{X}_{2}\right)$ terhadap Pengamalan Siswa ( $\left.\mathrm{Y}\right)$ mempunyai 
angka signifikan sebesar 0,599 $(\mathrm{p}>0,05)$. Hal mengartikan Prestasi Siswa $\left(\mathrm{X}_{2}\right)$ tidak memberi pengaruh signifikan terhadap Pengamalan Siswa ( Y).

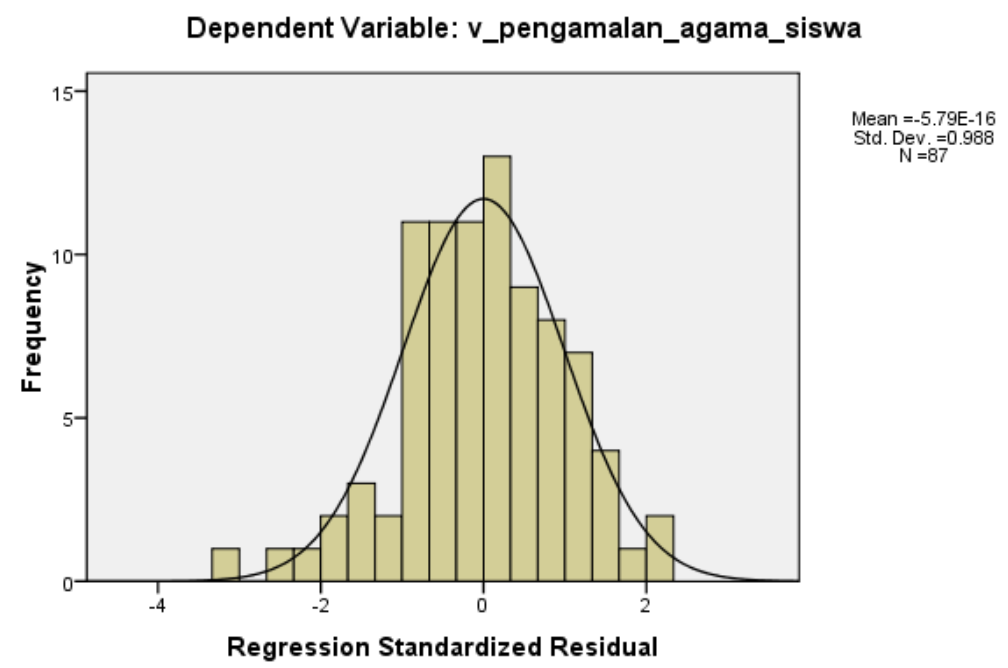

Gambar 1. Histogram distribusi normal pengujian hipotesis

Berdasarkan Gambar 1 terlihat sebaran data termasuk kategori normal ole karenanya syarat normalitas terpenuhi, sehingga data yang diperoleh kemudian diolah termasuk memenuhi kriteria valid.

\section{Pembahasan}

\section{Kreatifitas Guru $\left(\mathbf{X}_{1}\right)$}

Penelitian ini menggunakan asumsi bahwa Kreatifitas Guru $\left(\mathrm{X}_{1}\right)$, dan Prestasi Belajar $\left(\mathrm{X}_{2}\right)$ mempengaruhi Pengamalan Agama siswa (Y). Siswa SMKN 2 Malang kelas Xll mempunyai siswa laki-laki sejumlah 39 dan siswa perempuan sejumlah 48, sehingga keseluruhan 87 siswa. Variable kreatifitas guru $\left(\mathrm{X}_{1}\right)$ dari perolehan kuisioner skor tertinggi dengan nilai 4,05 sebagai poin tertinggi dari indikator 8 yaitu sifat menghargai, sedangkan poin terendah 3,11 dari indikator 7 yaitu berani mengambil resiko.

Kuisioner yang diberikan dari indikator 8 sifat menghargai terdapat 2 pernyataan yaitu (i) Guru memberi kesempatan kepada setiap siswa untuk bertanya di kelas dan (ii) Guru saya bersemangat bila menceritakan tentang pengalaman pribadinya. Pemberian kesempatan bertanya di dalam pembelajaran akan mendukung siswa aktif dalam pembelajaran. Demokrasi dalam belajar akan memeratakan hasil pembelajaran daalm kelas karena setiap siswa memiliki kesempatan yang sama dalam bertanya dan diskusi kelas. Mengingat dalam pembelajaran Agama Islam aspek yang dipelajari bermacam dari kebihupan pribadi muslim hingga kehidupan sosial dalm bermasyarakat. Kemudian hasil pembelajaran yang dilakukan bisa tercapai maksimal sesuai target. Guru 
bersemangat dalam menceritakan pengalaman pribadi sebagai contoh pengalaman yang telah dilewati diharapkan menjadi inspirasi sebagai perjalanan kehidupan kemudian bagi siswa.

Kuisioner dari indikator nomor 7 yaitu berani mengambil resiko mempunyai nilai skor terendah yaitu 3,11 mempunyai 2 pernyataan yaitu (i) guru mempertahankan gagasan atau pendapat meskipun mendapat sanggahan, (ii) guru melakukan hal-hal yang diyakini meskipun tidak disetujui orang lain. Skala Likert menunjukkan guru si SMKN 2 Malang memberi ruang kepada siswa atau guru mempunyai kreatifitas yang membuka pintu pertanyaan atau sanggahan ketika jawaban guru dinilai salah atau tidak tepat, sehingga siswa terlatih karakter kritisnya. Kekritisan dalam pengetahuan sebagai bagian dari bagian dari kemajuan. Kemudian, kreatifitas berupa keterbukaan untuk menyampaikan, mendengarkan, bahkan menyanggah pendapat semua siswa termasuk guru dapat dilakukan selama proses di kelas.

Indikator degan nilai tertinggi kedua yaitu kelancaran berpikir dengan skor mean 3,92. indikator 1 ini mempunyai 4 pernyataan, (i) guru saya lancar dalam menjelaskan materi, (ii) guru mengaitkan materi pelajaran dengan contoh kejadian yang ada di sekitar kita, (iii) guru menyampaikan kalimat dengan kalimat yang tepat. (iv). Skor mean 3,92 dan 4,05 memiliki nilai tidak beda jauh. Artinya kreatifitas guru di 2 bagian indikator ini memberi pengaruh terhadap siswa dalam menerima pendidikan Agama Islam di kelas. Penelitian ini tidak mencari peran dari kreatifitas guru terhadap kreatifitas siswa, sehingga membuka peluang bagi penelitian selanjutnya.

Indikator dengan nilai terendah kedua sebesar 3,3 yaitu indikator 6, merasa tertantang dengan kemajemukan. Indikator 6 mempunyai 2 pernyataan, (i) ketika berdiskusi di kelas guru mengemukakan gagasan atau masalah yang sulit, (ii) guru melibatkan diri dalam diskusi kelas. Artinya diskusi yang dipandu guru termasuk gagasan atau masalah mudah dalam sudut pandang siswa. Di sisi lain guru menurut siswa tidak terlalu campur tangan dalam diskusi kelas. Hal ini bisa dihubungkan dengan indikator 7, guru memberi ruang kepada siswa berdiskusi, menyanggah dan terbuka dalam perbedaan pendapat. Berdasar nilai total mean 3,25 kreatifitas guru bisa diartikan berada pada indikator no $6(3,3)$ dan $7(3,11)$.

\section{Prestasi Belajar $\left(\mathbf{X}_{2}\right)$}

Skor mean yang ditunjukkan pada Tabel 3 distribusi frekuensi nilai ulangan Pendidikan Agama Islam siswa XII sebanyak 20,69\% berada pada rentang 84,1- 86,1 dengan frekuensi 18 yang merupakan frekuensi terbanyak. Nilai terendah pada 3 rentang 90,1-92,1; 93,1 -95,1; 96,1 - 98,1 dengan frekuensi masing-masing sebanyak 7 dengan nilai prosentase $8,05 \%$. jika diurutkan dari tertinggi hingga terendah maka prosentase frekuensi nilai ulangan sebagai berikut, 20,96 \%; 17,24 $\% ; 14,94 \% ; 12,64 \% ; 10,34 \% ; 8,05 \% ; 8,05 \% ; 8,05 \% ; 8,05 \%$. Berdasarkan nilai di atas bisa 
dikatakan secara rata-rata nilai ulangan Pendidikan Agama Islam berada pada range 81,1-89,1 dan termasuk rata-rata baik.

\section{Pengaruh Kreatifitas Guru $\left(\mathrm{X}_{1}\right)$ dan Prestasi Belajar $\left(\mathrm{X}_{2}\right)$ terhadap Pengamalan Siswa ( $\mathbf{Y}$ )}

Tabel 5 menjelaskan bahwa korelasi yang diperoleh antara Kreatifitas guru $\left(\mathrm{X}_{1}\right)$ terhadap Pengamalan siswa (Y) sebesar 0,274. Nilai signifikan untuk korelasi adalah 1, sehingga hasil tersebut menunjukkkan korelasi antara Kreatifitas guru $\left(\mathrm{X}_{1}\right)$ dan Pengamalan siswa (Y) kecil sekali. Begitu juga korelasi antara Prestasi Belajar $\left(\mathrm{X}_{2}\right)$ dan Pengamalan siswa $(\mathrm{Y})$ diperoleh hasil lebih kecil lagi yaitu 0,077. menurut data ini yang lebih mempengaruhi mempengaruhi Pengamalan siswa $(\mathrm{Y})$ adalah Kreatifitas guru $\left(\mathrm{X}_{1}\right)$ dibandingkan Prestasi Belajar $\left(\mathrm{X}_{2}\right)$ siswa.

Data selanjutnya mempekuat data sebelumnya yaitu nilai F sebesar 3,546 dengan nilai signifikan 0, 033 yang ditunjukkan oleh Tabel 7. memberikan arti bahwa ada pengaruh dari variabel Kreatifitas Guru $\left(\mathrm{X}_{1}\right)$, dan Prestasi Belajar $\left(\mathrm{X}_{2}\right)$ terhadap variabel Pengamalan Agama Siswa (Y). Hal ini kemudian diperjelas oleh korelasi berganda pada analisis regresi dengan hasil pada Tabel 8. persamaan yang diperoleh $\mathrm{Y}=48,782+0,156 \mathrm{X}_{1}$ dan $\mathrm{Y}=48,782+0,0,053 \mathrm{X}_{2}$.

Kolom Standardized Coefficients Beta menunjukkan tingkat korelasi antara variabelvariabel, yaitu antara Kreatifitas guru $\left(\mathrm{X}_{1}\right)$ terhadap Pengamalan Siswa (Y), nilai signifikan yang diperoleh yaitu 0,269, sedangkan nilai signiifikan sebesar 0,012. Nilai ini lebih kecil dari 5\% (p < 0,05) menunjukkan terdapat pengaruh Kreatifitas guru $\left(\mathrm{X}_{1}\right)$ terhadap Pengamalan Siswa ( $\mathrm{Y}$ ). Standardized Coefficients Beta dengan nilai 0,055 yang menunjukkan korelasi Prestasi Siswa $\left(\mathrm{X}_{2}\right)$ terhadap Pengamalan Siswa ( Y) mempunyai angka signifikan sebesar 0,599 (p > 0,05) . Hal mengartikan Prestasi Siswa $\left(\mathrm{X}_{2}\right)$ tidak memberi pengaruh signifikan terhadap Pengamalan Siswa ( $\mathrm{Y})$.

Data-data tersebut menunjukkan yang mempengaruhi Pengamalan Agama Siswa (Y) adalah kreatifitas guru $\left(\mathrm{X}_{1}\right)$, sedangkan Prestasi Siswa $\left(\mathrm{X}_{2}\right)$ lebih kecil mempengaruhi Pengamalan Agama Siswa $(\mathrm{Y})$ dibandingkan kreatifitas guru $\left(\mathrm{X}_{1}\right)$. Kreatifitas guru pada SMKN 2 Malang meliputi pernyataan-pernyataan yang disebutkan dalam bagian metodologi. Guru mempunyai kewajiban mengelola kelas, sehingga siswa menjadikan ilmu yang diperoleh kemudian terdorong untuk mengamalkan secara sadar. Terkait dengan Pendidikan Agama Islam yang mayoritas dianut oleh siswa SMKN 2 Malang maka pengamlan siswa akan mendorong terciptanya suasana kondusif karena nilai-nilai kebaikan diamalkan di lingkungan mereka berada. Guru secara nyata memilik banyak peran dalam mempengaruhi perilaku siswa di sekolah melalui sitem pendidikan. Menurut Talajan (2012: 54), peranan guru mencakup aspek, kognitif, afektif, psikomotor. 
Prestasi siswa $\left(\mathrm{X}_{2}\right)$ sesuai data yang dipaparkan kecil sekali mempengaruhi Pengamalan Agama Siswa (Y). Prestasi di penelitian ini dilihat dari nilai ulangan yang diperoleh. Hal ini membuka peluang untuk penelitian lain yang menngunakan indikator prestasi siswa akan tetapi parameter yang digunakan selain ulangan harian atau penggunaan ulangan harian dipakai kembali tetapi tempat penelitian di sekolah yang berbeda.

\section{PENUTUP}

\section{Kesimpulan}

Berdasarkan penjelasan di atas kesimpulan penelitian ini antara lain:

1. Nilai rata-rata (mean) sebesar 67,09 untuk Pengamalan Siswa (Y), sedangkan kreatifitas guru $\left(\mathrm{X}_{1}\right)$ dengan nilai 88,26, dan prestasi siswa $\left(\mathrm{X}_{2}\right)$ dengan nilai sebesar 85,47.

2. Prestaasi siswa dilihat berdasar nilai ulangan Pendidikan Agama Islam siswa XII sebanyak $20,69 \%$ berada pada rentang 84,1- 86,1 dengan frekuensi 18 yang merupakan frekuensi terbanyak.

3. Pengukuran data menggunakan korelasi berganda diperoleh hasil bahwa Kreatifitas guru $\left(\mathrm{X}_{1}\right)$ mempunyai pengaruh terhadap Pengamalan Siswa $\left(\mathrm{Y}_{1}\right)$. Hal ini terlihat dari nilai Standardized Coefficients Beta sebesar 0,269 yang dibandingkan dengan nilai signifikan 0,012 dengan taraf nyata 5\%. Variabel lain yaitu Prestasi Siswa $\left(\mathrm{X}_{2}\right)$ tidak memberi pengaruh signifikan pada Pengamalan Siswa ( Y). Hal ini terlihat dari nilai Standardized Coefficients Beta sebesar 0,055.

4. Kreatifitas guru $\left(\mathrm{X}_{1}\right)$ mempunyai pengaruh terhadap Pengamalan Siswa (Y), sedangkan Prestasi Siswa $\left(\mathrm{X}_{2}\right)$ pengaruHnya kecil sekali terhadap Pengamalan Siswa ( $\left.\mathrm{Y}\right)$.

\section{Saran}

1. Banyaknya indikator dalam malakukan penilaian Pendidikan Agama Islam di sekolah menjadikan pentingnya dilakukan pengukuran berkala keberhasilan pendidikan. Pihak sekolah bisa bekerjasama dengan universitas atau lembaga lain yang mengkaji pendidikan.

2. Peluang mengenai keberadaan berbagai variabel pengukuran sehingga memperbanyak peluang untuk melakukan perbandingan dan pengukuran variabel penelitian. Hal ini dapat membantu pihak sekolah dalam mengevaluasi pendidikan di institusi terkait.

\section{DAFTAR RUJUKAN}

Burhanuddin, H. (2014). Rekontruksi Sistem Pendidikan Agama Islam di Indonesia. Muaddib volume 4 nomor 2.

Djohar, M., S. 2006. Guru, Pendidikan dan Pembinaannya, Penerapannya dalam Pendidikan dan UU Guru. Yogyakarta: Grafika Indah. 
Muhaimin. 2010. Pengembangan Kurikulum Pendidikan Agama Islam di Sekolah, Madrasah, dan Perguruan Tinggi. Jakarta: Rajagrafindo Persada.

Muhamad Faisal Ashaari, M., F., Ismail, Z., Puteh, P., Samsudin, M., A., Ismail, M., Kawangit, R., Zainal, H., Nasir, B., M., and Ramzi, M., I. 2012. An Assessment of Teaching and Learning Methodology in Islamic Studies. Procedia-Social and Behaviour Sciences 59 page 618-626.

Nisfianoor, M. 2009. Pendekatan statistik Modern untuk Ilmu sosial. Salemba Humanika: Jakarta.

Nugroho, M., A., dan Ni'mah, K. 2018. Konsep Pendidikan Islam Berwawasan Kerukunan pada Masyarkat Multikultural. Millah: Jurnal Studi Agama volume 17 nomor 2 halaman 337-378.

Othman, N. 2014. A Comparative Study Between Western and Islamic Perspectives on Human Development and Life-Friendly Environment. Online Journal of Research in Islamic Studies volume 1 no. 1.

Rustan, E. 2018. De-radicalization in the Implementation of Islamic Education Curriculum in SMA Masamba South Sulawesi. Dinamika Ilmu, volumen 18 nomor 2.

Subhan, F. (2013). Konsep Pendidikan Islam Masa Kini. Jurnal Pendidikan Agama Islam volume 2 nomor 2.

Sudjana, Nana. 2010. Penilaian Hasil Proses Belajar Mengajar. (Cet. XV). Bandung: PT. Remaja Rosdakarya

Sugiyono. 2011. Metode Penelitian Kombinaasi ( Mixed Methods). Alfabeta: Bandung.

Talajan, G. 2012. Menumbuhkan Kreativitas dan prestasi Guru. Yogyakarta: Laksbang Presindo.

Zaini, Akhmad dan Darwan Setyono. 2020. Hubungan antara Nilai Sikap dengan Prestasi Akademik pada Mata Pelajaran Pendidikan Agama Islam. JURNAL TADRIS, Volume 14, Nomor 1, Juni 2020 Halaman 41-58. 